\section{EFFECTS OF SIMVASTATIN AND CHOLESTYRAMINE ON LIPOPROTEIN PROFILE IN HYPERLIPIDAEMUA OF NEPHROTIC SYNDROME}

\author{
A. J. RABELINK ${ }^{1}$ \\ D. W. ERKELENS ${ }^{2}$ \\ R. J. HENÉ ${ }^{1}$ \\ J. A. JOLES ${ }^{1}$
}

H. A. KOOMANS ${ }^{1}$

Departments of Nephrology and Hypertension, ${ }^{1}$ and Internal Medicine, ${ }^{2}$ University Hospital Utrecht, Catharijnesingel 101, 3511 GV Utrecht, The Netherlands

Summary The efficacy, safety, and tolerability of
simvastatin ( $20 \mathrm{mg}$ twice a day) in the treatment of hyperlipidaemia due to unremitting nephrotic syndrome was compared with that of cholestyramine $(8 \mathrm{~g}$ twice a day) in a crossover trial in ten patients. Two patients were taken off the protocol, one because he could not tolerate cholestyramine and one because of non-compliance with the cholestyramine regimen. No clinical or laboratory adverse experiences were noticed during the study in the other eight patients. Simvastatin was significantly more effective than cholestyramine in reducing the hyperlipidaemia-it produced a $36 \%$ decrease in total cholesterol and a $39 \%$ decrease in low density (LDL)-cholesterol, whereas cholestyramine reduced total cholesterol by $8 \%$ and LDLcholesterol by $19 \%$. With simvastatin the apolipoprotein B level decreased by $30 \%$, whereas the apolipoprotein A level increased by $10 \%$.

\section{Introduction}

THERE is no unanimity on the clinical consequences of the hyperlipidaemia of the nephrotic syndrome, which is characterised by raised total and low-density (LDL) cholesterol levels with normal or reduced high-density lipoprotein (HDL) cholesterol, ${ }^{1,2}$ an abnormality associated with accelerated atherosclerosis in non-nephrotic patients. ${ }^{3}$ Studies demonstrating accelerated atherosclerosis were confounded by inclusion of patients with diabetes mellitus, on steroid treatment, or with renal failure, ${ }^{4}$ whereas studies that did not establish a relation between nephrotic hyperlipidaemia and accelerated atherosclerosis can be criticised for inclusion of patients who were in remission and for not specifying death due to chronic renal failure. ${ }^{5}$

Hyperlipidaemia may also be regarded as a pathogenic factor in the development of focal and segmental glomerulosclerosis. ${ }^{6}$ Recent studies have shown that lipidlowering therapy reduced the incidence of focal glomerulosclerosis in a remnant kidney model ${ }^{7}$ and in obese rats in which glomerulosclerosis develops spontaneously. ${ }^{8}$
In addition, cholesterol supplementation accelerated the development of focal glomerulosclerosis and aggravated proteinuria in a rat model of the nephrotic syndrome. ${ }^{9}$

Few controlled studies have been carried out to assess the efficacy of lipid-lowering drugs in nephrotic hyperlipidaemia, and none of the drugs investigated restored to normal the lipid abnormalities associated with nephrotic syndrome. ${ }^{10,11}$ Recently, inhibition of the ratecontrolling enzyme of cholesterol synthesis (3-hydroxy-3methylglutaryl coenzyme A reductase, or HMG CoA reductase) has proved to be a very effective treatment in primary hypercholesterolaemia ${ }^{12,13}$ and secondary hypercholesterolaemia due to diabetes mellitus. ${ }^{14}$ Here we describe a crossover trial comparing the effects of 6 weeks' treatment with the HMG CoA reductase-inhibitor simvastatin $^{13}$ with those of the bile-acid binding resin cholestyramine on the lipoprotein pattern in ten patients with long-standing unremitting nephrotic syndrome.

\section{Patients and Methods}

\section{Patients}

The subjects were ten patients with nephrotic syndrome as defined by proteinuria in excess of $3 \mathrm{~g}$ per day. Informed consent was obtained and the study was approved by the University Hospital Committee for Studies in Humans. All patients had a total cholesterol of $8.5 \mathrm{mmol} / 1$ or more at the start of the study. Subjects were aged 30-75 years; seven were men. The diagnoses (biopsy proven) were: membranous glomerulonephritis (6), focal glomerulosclerosis (2), mesangiocapillary glomerulonephritis (1), and lupus nephritis (1). None of the patients had diabetes mellitus. No patient was known to have a family history of lipid abnormalities. Thyroid function was normal in all patients. The known duration of the nephrotic syndrome ranged from 8 to 46 months. In all patients oedema was treated with diuretics. One patient also received steroids. Dosages of diuretic and steroid medication were unchanged during the study period.

TABLE I-EFFECTS OF SIMVASTATIN AND CHOLESTYRAMINE ON LIVER FUNCTION AND CREATININE KINASE IN 8 PATIENTS WITH NEPHROTIC SYNDROME

\begin{tabular}{|c|c|c|c|c|c|}
\hline- & Placebo & $\begin{array}{l}\text { Simva- } \\
\text { statin }\end{array}$ & Placebo & $\begin{array}{l}\text { Cholesty- } \\
\text { ramine }\end{array}$ & $\begin{array}{l}\text { Ref } \\
\text { range }\end{array}$ \\
\hline $\begin{array}{l}\text { ALT }(\mathrm{U} / \mathrm{l}) \\
\text { AST }(\mathrm{U} / \mathrm{l}) \\
\text { Alkaline phophatase } \\
(\mathrm{U} / 1) \\
\text { Total bilinubin } \\
(\mu \mathrm{mol} / 1) \\
\text { Creatinine kinase } \\
(\mathrm{U} / 1)\end{array}$ & $\begin{array}{c}13 \cdot 6(3 \cdot 4) \\
15 \cdot 2(1 \cdot 7) \\
69 \cdot 5(21 \cdot 1) \\
5.5(2 \cdot 5) \\
536(17 \cdot 7)\end{array}$ & $\begin{array}{c}16 \cdot 4(7 \cdot 7) \\
15 \cdot 7(51) \\
66 \cdot 9(17 \cdot 8) \\
6.0(2 \cdot 3) \\
57 \cdot 4(24 \cdot 2)\end{array}$ & $\begin{array}{l}16 \cdot 0(7 \cdot 8) \\
16.9(62) \\
67.5(22 \cdot 4) \\
5.3(2 \cdot 7) \\
539(23 \cdot 8)\end{array}$ & $\begin{array}{l}20 \cdot 7(16 \cdot 5) \\
22 \cdot 6(81) \\
72 \cdot 2(28 \cdot 1) \\
5 \cdot 9(31) \\
56 \cdot 7(257)\end{array}$ & $\begin{array}{c}2-30 \\
2-30 \\
35-140 \\
0-17 \\
10-120\end{array}$ \\
\hline
\end{tabular}

Findings given as means (SD).

There were no significant changes between the various treatment periods. ALT = alanine aminotransferase; AST = aspartate aminotransferase. Ref range $=$ reference range.

V. BERAL AND OTHERS: REFERENCES-continued

\footnotetext{
5. Weiss NS, Sayvetz TA. Incidence of endometrial cancer in relation to the use of oral contraceptives. N Engl F Med 1980; 302: 551-54.

6. Kaufman DW, Shapiro S, Slone $D$, et al. Decreased risk of endometrial cancer among oral-contraceptive users $N$ Engl f Med 1980; 303: 1045-47.

7. Centers for Disease Control cancer and steroid hormone srudy. Oral contraceptrve use and the risk of endometrial cancer. $\mathcal{F} A M A 1983 ; 249 ; 1600-04$.

8. Henderson BE, Casagrande JT, Pike MC, Mack T, Rosario I, Duke A. The epidemiology of endometrial cancer in young women $\mathrm{Br} f$ Cancer 1983, 47: $749-56$

9 Casagrande JT, Louie EW, Pike MC, Roy S, Ross RK, Henderson BE. "Incessant ovulation" and ovarian cancer. Lancet $1979 ;$ ii $\cdot 170-73$.

10. Cramer DW, Hutchinson GB, Welch WR, Scully RE, Knapp RC. Factors affectung the association of oral contraceptives and ovarian cancer $N$ Engl f Med 1982; 307: $1047-51$.

11. Centers for Disease Control cancer and steroid hormone study. Oral contraceptive use and the risk of ovarian cancer. $7 A M A 1983 ; 249: 1596-99$.

12. Scott JS. Sex hormones and gynaecological cancer. Br Med F 1982; 284: 1657-58.
}

13. Royal College of General Practinoners. Oral contraceptives and health. London Pitman, 1974 .

14. World Health Organisanon. International classification of diseases, 8th revision. Geneva: WHO, 1965.

15. Breslow NE, Day NE. Statistical methods in cancer research, vol II-the design and analyses of cohort studies. Lyon: IARC Scientific Publications 82, 1987.

16. Miettinen OS. Estimability and estumation in case-referrant studies. Am 9 Epidemol 1976; 103: 226-35.

17. Department of Medical and Public Affaurs, George Washington University Medical Center. Population Reporr, Series A, No 1. Washington DC, 1974.

18. La Vecchia C, Franceschi S, Decarli A, Fasoli M, Gentile A, Tognoni G "Pap" smear and the risk of cervical neoplasia: quantitative estimates from a case-control study. Lancet 1984 ; ii: $779-82$.

19. MacGregor EJ, Moss S, Parkun DM, Day NE. A case-control study of cervical screening in north east Scorland. Br Med $f$ 1985; 290: 1543-46.

20. Royal College of General Practitoners' Oral Contraceprion Study. Further analyses of mortality in oral contraceptive users. Lancet 1981; i: 541-46. 


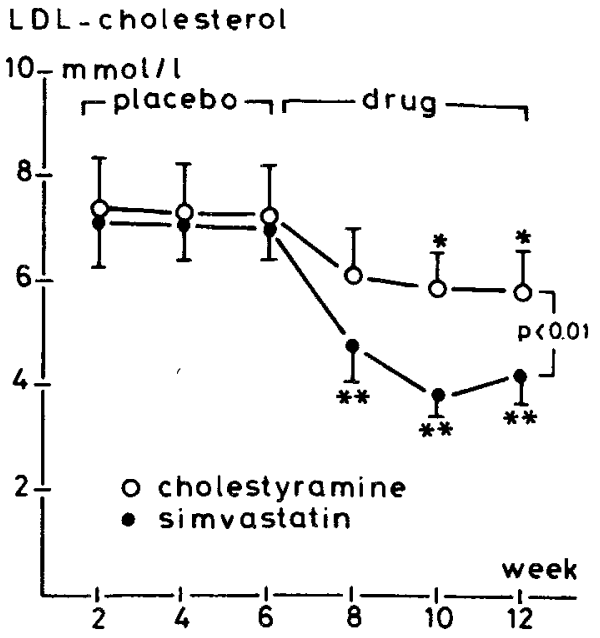

Fig 1-Effects of placebo (week 0 through 6) and of simvastatin and cholestyramine (week 7 through 12) on LDL-cholesterol in 8 patients with nephrotic syndrome.

${ }^{\star} \mathrm{p}<0.05,{ }^{\star \star} \mathrm{p}<0.01$, compared to corresponding placebo period. " $p<0.01$ " denotes significance of the differences at week 12 . Values are mean (SE).

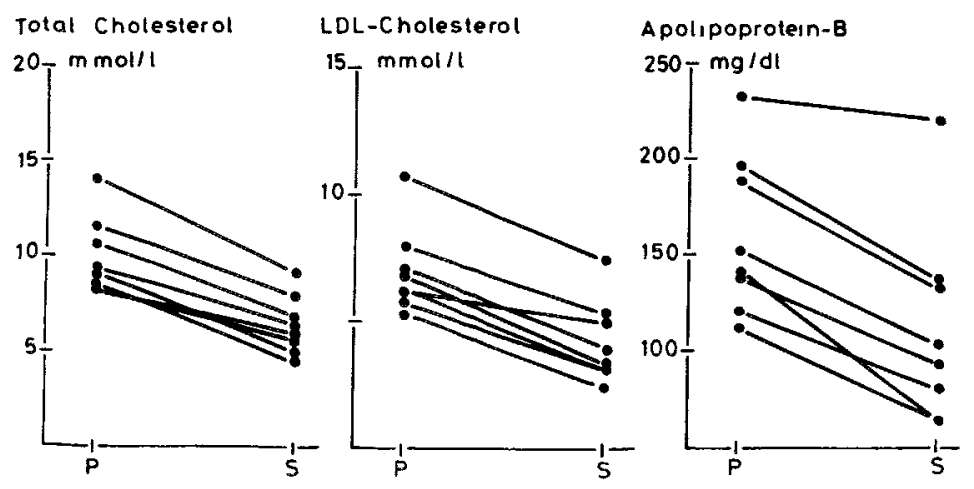

Fig 2-Plasma levels of total and LDL cholesterol and apolipoprotein-B in 8 patients with nephrotic syndrome after six weeks of treatment with placebo $(P)$ and six weeks of treatment with simvastatin (S).

\section{Study Design and Laboratory Methods}

A diet low in saturated fat and low in cholesterol $(<300 \mathrm{mg}$ ) was prescribed by a dietitian and continued for 30 weeks. The first 6 weeks were considered the equilibration period. During the second 6 weeks the patients received a placebo (twice a day) and information collected during this period served as baseline data. Then the patients were randomly assigned to a 6 weeks' treatment period with simvastatin $20 \mathrm{mg}$ twice a day or cholestyramine $8 \mathrm{~g}$ twice a day. After a wash-out period of 6 weeks, during which the patients again received a placebo, patients were given the alternative active treatment for 6 weeks. Every 2 weeks a blood sample was taken, after a $12 \mathrm{~h}$ overnight fast, for plasma lipids and routine laboratory tests for: haematological variables; renal and liver function; creatinine phosphokinase; uric acid; glucose; total protein, electrolytes and urine analysis. A full ophthalmological examination was done at the start and end of the study. At every visit the patients were questioned about adverse experiences and a brief physical examination was done. Adherence to therapy was assessed by counting the capsules and packs. Compliance was over $95 \%$.

Serum cholesterol and triglycerides were determined by enzymatic methods. ${ }^{15,16}$ HDL-cholesterol was determined after precipitation of VLDL and LDL. ${ }^{17,18} \mathrm{LDL}$ cholesterol was calculated from total serum cholesterol, triglycerides, and HDL cholesterol by the Friedewald formula. ${ }^{19}$ Apolipoprotein A-1 and B were determined by immunoturbidimetry. ${ }^{20}$

\section{Statistics}

Values are expressed as means (SD) except in fig 1. Results were analysed with two-way analysis of variance for a randomised block

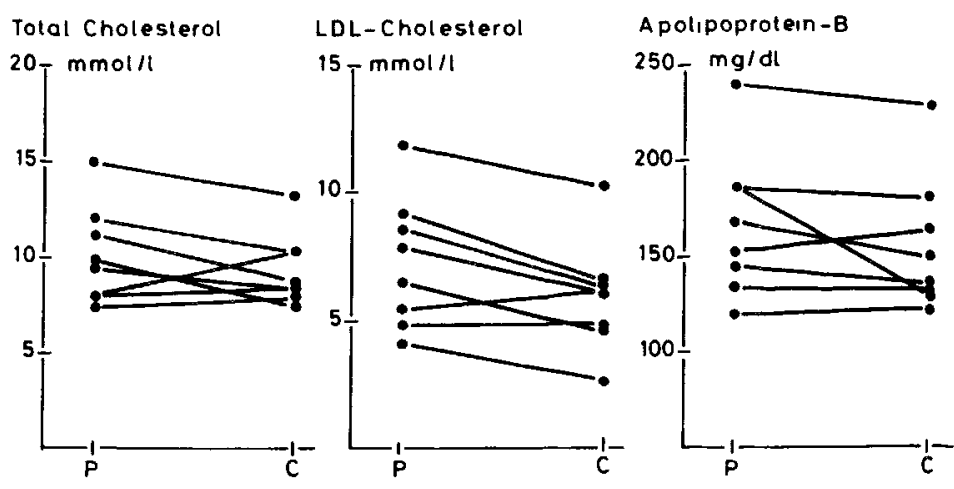

Fig 3-Plasma levels of total and LDL cholesterol and apolipoprotein-B in 8 patients with nephrotic syndrome after six weeks of treatment with placebo $(P)$ and six weeks of treatment with cholestyramine $(C)$.

design. The treatment variance ratios obtained by this method show whether a variable is significantly altered by simvastatin or cholestyramine, and whether the effect of simvastatin on a variable differs from that of cholestyramine. If these variance ratios reached statistical significance, the differences between the means were analysed at $5 \%$ and $1 \%$ significance levels by the least significance difference test.

\section{Results}

At the end of the equilibration period patients had a raised cholesterol " $(10.0$ [1.9] $\mathrm{mmol} / \mathrm{l})$, LDL-cholesterol $(7.7$ [1.7] $\mathrm{mmol} / \mathrm{l})$, and triglyceride levels $(4.3[1.5] \mathrm{mmol} / \mathrm{l})$. These values exceeded the 95 th percentile for age and sex matched controls. ${ }^{21.22}$ The HDL-cholesterol level was within the normal range $(0.89[0 \cdot 16] \mathrm{mmol} / \mathrm{l})$. The mean serum albumin concentration of the study population was $26 \cdot 1[9 \cdot 7] \mathrm{g} / \mathrm{l}$, the mean $24 \mathrm{~h}$ urinary albumin excretion was $6.8[3.3] \mathrm{g} /$ day. The patients had normal renal function, except for one patient with mesangiocapillary glomerulonephritis, who had a creatinine clearance of 47 $\mathrm{ml} / \mathrm{min}$.

Simvastatin was well tolerated by all patients. No clinical or laboratory evidence of adverse effects was noticed. About $2 \%$ of the patients treated with the HMG CoA reductase inhibitor lovastatin have persistent symptomless increases in aminotransferases, and occasionally myositis has been reported. ${ }^{23}$ There were no significant changes in liver enzymes and creatinine kinase during either treatment period (table I). However, aminotransferase concentrations tended to be higher during cholestyramine therapy because of the raised levels in one subject who had ingested alcohol in the two days before this particular laboratory investigation, but had shown normal values 2 weeks previously, while also on cholestyramine. Although the possibility of cataract induction, as has been reported in dogs on very high doses of lovastatin, has raised major concern, clinical studies have indicated no detectable effect of lovastatin on human lens. ${ }^{23}$ Ophthalmological examination in our patients revealed no additional lenticular opacities after the study. Two patients had to be taken off the protocol, one (with lupus nephritis) because she was not taking her cholestyramine and one (with membranous glomerulonephritis) because of diarrhoea and vomiting while on cholestyramine. Further data analysis was done on the eight patients who completed the study.

Simvastatin caused a $36 \%$ decrease in total cholesterol $(\mathrm{p}<0.01)$ and a 39\% decrease in LDL-cholesterol (fig 1) $(\mathrm{p}<0.01)$ within 4 weeks, to reach levels within the upper limit of normal values. With cholestyramine total cholesterol 
TABLE II-EFFECTS OF SIMVASTATIN AND CHOLESTYRAMINE ON LIPOPROTEIN PROFILE AND RENAL FUNCTION IN 8 PATIENTS WITH NEPHROTIC SYNDROME

\begin{tabular}{|c|c|c|c|c|c|}
\hline 一 & Placebo & Simvastatin & Placebo & $\begin{array}{l}\text { Cholesty- } \\
\text { ramine }\end{array}$ & $\mathrm{p} \ddagger$ \\
\hline $\begin{array}{l}\text { Total cholesterol } \\
(\mathrm{mmol} / \mathrm{l})\end{array}$ & $10.01(2.03)$ & $6.44(1.66) \dagger$ & $10 \cdot 13(255)$ & $935(1.92)$ & $<0.01$ \\
\hline $\begin{array}{l}\text { LDL-cholesterol } \\
(\mathrm{mmol} / \mathrm{l})\end{array}$ & $7.02(171)$ & $4.28(1.58) \dagger$ & $7 \cdot 30(2 \cdot 60)$ & $5 \cdot 90(2 \cdot 17)^{\star}$ & $<0.01$ \\
\hline $\begin{array}{l}\text { HDL-cholesterol } \\
(\mathrm{mmol} / \mathrm{l})\end{array}$ & $0.99(030)$ & $1.20(031)$ & $0.90(019)$ & $1 \cdot 11(0.41)$ & \\
\hline $\begin{array}{l}\text { Triglycerides } \\
\text { (mmol/1) } \\
\text { Apolipoprotein }\end{array}$ & $4.45(1.62)$ & $273(1.23)^{\star}$ & $428(1.56)$ & $5 \cdot 19(4 \cdot 02)$ & $<0.05$ \\
\hline $\begin{array}{l}\text { A-I (g/l) } \\
\text { Apolipoprotein B }\end{array}$ & $1.97(0.31)$ & $2 \cdot 17(0.34)^{\star}$ & $1.98(0.28)$ & $2.06(0.27)$ & NS \\
\hline $\begin{array}{l}(\mathrm{g} / \mathrm{l}) \\
\text { Creatinine }\end{array}$ & $1.60(0.42)$ & $112(0.52) t$ & $1.67(0.38)$ & $1.56(0.35)$ & $<0.01$ \\
\hline $\begin{array}{l}\text { (umol/1) } \\
\text { Albumin (g/1) }\end{array}$ & $\begin{array}{l}96(43) \\
25(7)\end{array}$ & $\begin{array}{l}98(32) \\
30(10)\end{array}$ & $\begin{array}{l}99(40) \\
24(8)\end{array}$ & $\begin{array}{l}90(35) \\
26(10)\end{array}$ & $\begin{array}{l}\text { NS } \\
\text { NS }\end{array}$ \\
\hline
\end{tabular}

Findings given as means $(\mathrm{SD}) ;{ }^{\star} \mathrm{p}<0.05, \mathrm{tp}<0.01$, compared with corresponding placebo period.

$\ddagger$ Comparison between simvastatin and cholestyramine. NS $=$ No significant differences between the two placebo periods.

TABLE III-RENAL FUNCTION BEFORE AND AT END OF THE STUDY $(\mathbf{n}=8)$

\begin{tabular}{l|c|c|c}
\hline \multicolumn{1}{c|}{-} & Before & After & $\mathrm{p}$ \\
\hline Creatinine $(\mu \mathrm{mol} / \mathrm{l})$ & $102(34)$ & $97(33)$ & NS \\
Albumin $(\mathrm{g} / \mathrm{l})$ & $26(3)$ & $30(4)$ & NS \\
Albuminuria $(\mathrm{g} / 24 \mathrm{~h})$ & $7 \cdot 6(3 \cdot 2)$ & $6 \cdot 4(4 \cdot 5)$ & $\mathrm{NS}$ \\
\hline
\end{tabular}

fell by $8 \%$ to a plateau at the 4 th week (not significant) and LDL-cholesterol fell by $19 \%$ (fig 1 ) $(p<0.05)$; both reductions were significantly less than those produced by simvastatin therapy $(p<0 \cdot 01)$. For simplicity the effects of treatment are presented in table II as the values during the last week of the various 6-week phases of the trial. Apolipoprotein B fell by $30 \%$ during simvastatin $(p<0 \cdot 01)$ while apolipoprotein $A$ increased by $10 \%(p<0.05)$ (fig 2 ). Cholestyramine had no effect on either apolipoprotein (fig 3). Triglyceride levels tended to rise during cholestyramine therapy, and to decrease during simvastatin treatment in all but one patient, but these changes were not significant. Simvastatin was associated with a small increase in HDLcholesterol in all but one patient. There was no significant effect of either treatment on serum creatinine or albumin (table II). The drugs had no effect on the degree of nephrosis (table III).

\section{Discussion}

The purpose of the present study was to assess the efficacy, tolerability, and safety of two lipid-lowering drugs, the HMG CoA reductase-inhibitor simvastatin and the bile-acid-binding resin cholestyramine, in the treatment of hyperlipidaemia of nephrotic syndrome. Before treatment, our patients had the well-known characteristics of nephrotic hyperlipidaemia - very high total cholesterol, triglyceride, and LDL cholesterol values. ${ }^{3,4}$ Simvastatin lowered total cholesterol, LDL-cholesterol, and triglycerides to the upper limit of the normal range (although still above target values), whereas cholestyramine had only a moderate effect on total cholesterol and LDL-cholesterol and induced a tendency towards higher plasma triglycerides. The LDL-cholesterol decrease during simvastatin was associated with a nonsignificant increase in HDL-cholesterol. Both these changes may decrease the risk of coronary heart disease. ${ }^{24}$ This alteration of lipoprotein profile was also reflected in the decrease in apolipoprotein $B$ (the major LDL protein) and the rise in apolipoprotein A-I (the major HDL protein). Again, these effects were more pronounced during the simvastatin period than during treatment with cholestyramine. During the study no side-effects were noticed. Simvastatin was well tolerated. Two patients had to be taken off the protocol during cholestyramine treatment, one because of gastrointestinal complaints and one because of non-compliance.

Few controlled studies have been done to assess the efficacy of lipid-lowering drugs in nephrotic hyperlipidaemia. Colestipol, another bile-acid binding resin, has been reported to lower total cholesterol and LDLcholesterol in seven patients with nephrotic syndrome who were similar to the patients in this study as regards lipid abnormalities and degree of nephrosis. ${ }^{9}$ Colestipol did not restore lipid concentrations to normal (total cholesterol decreased from 10.2 to $8.2 \mathrm{mmol} / 1$; LDL cholesterol decreased from 7.7 to $5.2 \mathrm{mmol} / 1$ ); it raised plasma triglyceride levels. In the same study, probucol, a substituted dithioacetal derivative, had equally moderate effects on total cholesterol and LDL-cholesterol.9 In another study this drug reduced not only total cholesterol and LDL-cholesterol but also the HDL-cholesterol levels, thereby leaving the LDL-to-HDL cholesterol ratio unchanged. ${ }^{10}$ Finally, treatment of the nephrotic hyperlipoproteinaemia with clofibrate has been associated with serious muscle toxicity. ${ }^{25} \mathrm{~A}$ small uncontrolled study of the effects of lovastatin, another HMG CoA reductase inhibitor, in three patients with nephrotic hyperlipidaemia ${ }^{26}$ has shown that lovastatin had effects similar to those of simvastatin in our study.

How hyperlipidaemia arises in the nephrotic syndrome is not known at present. Hepatic overproduction of precursor lipoproteins has been advanced as the main effector mechanism. ${ }^{26,27}$ The hypertriglyceridaemia is probably due to delayed lipolysis. ${ }^{26,28,29}$ Reduced activity of LDLreceptors or decreased lipoprotein lipase acivity may have contributed to the delayed lipolysis. ${ }^{26,29}$ It is assumed that the lipid-lowering effects of HMG CoA reductase inhibitors are mediated by an increased expression of LDL-receptors, rather than by primary inhibition of lipoprotein synthesis in the liver..$^{30}$ By interrupting the enterohepatic circulation of bile acids, cholestyramine also enhances LDL-receptor activity, ${ }^{31}$ but its effectiveness is limited by simultaneous increase in hepatic lipoprotein synthesis. The limited effects of cholestyramine on lipid profile in nephrotic syndrome compared with simvastatin in our patients may therefore indicate that inhibition of hepatic synthesis of lipoproteins contributes to the lipid-lowering effects of simvastatin, and that enhanced lipoprotein synthesis, rather than decreased catabolism caused the hyperlipidaemia of nephrotic syndrome. Support for these suggestions comes from observations of increased HMG CoA reductase activity in nephrotic rats ${ }^{32}$ and from kinetic studies in three nephrotic patients showing that they did not have decreased fractional catabolic rates for LDL (which can be taken as a measure of LDL receptor activity) and that lovastatin lowered LDL without affecting the fractional catabolic rate..$^{26}$

We conclude that the HMG COA reductase inhibitor simvastatin can substantially reduce the hyperlipidaemia associated with the nephrotic syndrome. It seems to be more effective and is tolerated better than is the bile-acid binding resin cholestyramine, which is presently the drug of choice in the treatment of nephrotic hyperlipidaemia. Whether 
these effects on the nephrotic hyperlipidaemia may, as has been observed in experimental studies in rats, retard progression to renal failure in human glomerulosclerosis, remains to be established.

We thank Merck, Sharp and Dohme Research Laboratories Rahway, New Jersey, USA for providing simvastatin; Dr L. A. M. de Vries for ophthalmological examinations; and Mrs C. Benschop for technical assistance.

Correspondence should be addressed to A. J. R.

\section{REFERENCES}

1. Appel GB, Blum CB, Chien S, Kunis CL, Appel AS. The hyperlipidemia of nephrotic syndrome: Relation to plasma albumin concentration, oncotic pressure, and viscosiry. $N$ Engl f Med 1985; 312: 154448

2. Bernard DB. Metabolic abnormalities in nephrotic syndrome: pathophysiology and complications. In: Brenner BM, Stein JA, eds. Controversies in nephrology, vol 9 , the nephrotic syndrome. New York: Churchill Livingstone, 1982.

3. Stamler J. Population studies. In: Levy R, Rifkind BM, Dennis BH, et al, eds. Nutrition, lipids and coronary heart disease. New York. Raven, 1979: 25-28.

4. Curry RC, Roberts WC. Status of the coronary arteries in the nephrotic syndrome (analysis of 20 necropsy patients aged 15 to 35 years to determine if coronary atherosclerosis is accelerated). Am $\mathcal{F}$ Med 1977; 63: 183-92.

5. Mallick NP, Short CD. The nephrotic syndrome and ischaemic heart disease. Nephron $1981 ; 27: 54-57$

6. Diamond JR, Karnovsky MJ. Focal and segmental glomeruloscleorsis: analogres to atherosclerosis. Kidney Int 1988; 33: 917-24.

7. Kasiske BL, O'Donnell MP, Garvis WJ, Keane WF. Pharmacologic treatment of hyperlpidemia reduces glomerular injury in rat 5/6 nephrectomy Model of chronic renal fallure. Circ Res 1988; 62: 367-74.

8. Kasiske BL, O'Donnell MP, Cleary MP, Keane WF. Treatment of hyperlupidemia reduces glomerular injury in obese Zucker rats. Kidney Int 1988; 33: 667-72.

9. Diamond JR, Kamovsky MJ. Exacerbation of chronic aminonucleoside nephrosis by dietary cholesterol supplementation. Kidney Int 1987; 32: 671-77.

10. Valen A, Gelfand J, Blum C, Appel GB. Treatment of the hyperlipidemia of the nephrouc syndrome: a controlled trial. Am F Kidney Dis 1986; 8: 388-96.

11. Iida $H$, Asaka $M$, Fujita $M$, Nishino A, Sasayama $S$. Effect of probucol on hyperlipidema in patients with nephrotic syndrome. Nephron 1987; 47: 280-83.

12. Illingworth DR, Sexton GI. Hypercholesterolemic effects of mevinolin in patients with heterozygous familial hypercholesterolemia. 7 Cln Invest 1984; 74: 1972-78.

13. Mol MJ, Erkelens DW, Gevers Leuven JA, Schouren JA, Stalenhoef AF. Effects of synvinolin (MK-733) on plasma lipids in familial hypercholesterolaemia. Lancet 1986; ii: $936-39$

14. Garg A, Grundy SM. Lovastatm for lowering cholesterol levels in non-insulindependent diabetes mellitus. $N$ Engl 7 Med 1988; 318: 81-86.

15. Roschlau P, Bernt E, Gruber W. Enzymatısche Bestımmung der gesantcholesterins in Serum. 7 Clin Chem Clin Biochem 1974; 12: 403-07.

16. Giegel JL, Ham AB, Clema W. Manual and semi-automated procedures for measurement of triglycerides in serum. Clin Chem 1975; 64: 45-50.

17. Lopez-Virella MF, Stone J, Ells S, Goldwell JA. Cholesterol determination in high density lipoproteins separated by three different methods. Clin Chem 1977; 23: $882-84$

18. Demacker PNM, Hijmans AGM, Vos-Jansen HE, vam't Laar A, Janssen AP A study of the use of polyethylene glycol in estimating cholesterol in high density lipoprotein. Clin Chem 1980; 26: 1775-79.

19. Friedewald WT, Levy RJ, Frederickson DS. Estumation of the concentration of low-density lipoproten cholesterol in plasma without use of the preparatuve ultracentrufuge. Clin Chem 1972; 18: 499 .

20 Price $\mathrm{CP}$, Spencer $\mathrm{K}$, Whicher J. Light-scartering immunoassay for specific proteins a review. Ann Cln Biochem 1983, 20: 1-14.

21. Knuiman JT, Katan MB. Serum cholesterol levels in the Netherlands as compared with those in the United States. Ned Tyjdschr Geneeskunde 1985; 129: 2500-05

22. Rifkınd BM, Segal P. Lipıd Research Clinics Program reference values for hyperlipidemia and hypolipidemia. 7AMA 1983; 250: 1869-72.

23. Tobert JA. New developments in lipid-lowering therapy. the role of unhibitors of hydroxymethylglutaryl coenzyme A reductase Circulaton 1987; 76: 534-38.

24. Miller GJ. High density lipoproteins and atherosclerosis. Annu Rev Med 1980; 31: $97-108$.

25. Bridgeman JF, Rosen SM, Thorp JM. Complications during clofibrate treatment of nephrotic syndrome hyperlipoproteinaemia. Lancet 1972; i1: 506.

26. Vega GL, Grundy SM. Lovastatin therapy in nephrotic hyperlipidemia: Effects on lipoprotein metabolism. Kidney Int 1988; 33: 1060-68

27. Marsh JB Lipoprotein metabolism in experimental nephrosis. 7 Lipid Res 1984; 25: $1619-23$

28. McKenzie IFL, Nestel PJ Studies on the turnover of triglyceride and esterified cholesterol in subjects with a nephrotic syndrome. 7 Clin Invest 1986; 47: 1685-95.

29. Garber DW, Gottlieb BA, Marsh JB, Sparks CE. Catabolism of very low density lipoproteins in experimental nephrosis f Cln Invest 1984; 74: 1375-83.

30. Bilhemer DW, Grundy SM, Brown MS, Goldstein JL. Mevinolin and colestupol stumulate receptor mediated clearance of low density lipoprotein from plasma in familial hypercholesterolema heterozygotes. Proc Natl Acad Sci USA 1983; 80: 4124-28

31 Sheperd J, Packard CJ, Bicker S, Lawrie TDV, Morgan HG. Cholestyramine promotes receptor-mediated low-density-lipoprotein catabolssm $N$ Engl $f$ Med 1980; 302: 1219-22

32 Golper TA, Femgold KR, Fulford MH, Siperstem MD The role of crrculating mevalonate in nephrotic hypercholesterolemia in the rat $f$ Lipud Res 1986; 27: $1044-51$

\section{Preliminary Communication}

\section{GRANULOCYTE-ASSOCIATED IMMUNOGLOBULINS IN RENAL TRANSPLANT RECIPIENTS WITH CYTOMEGALOVIRUS INFECTION}

A. Debure $^{1}$
J. CARTRON
N. CHKOFF $^{1}$

\section{J. L. CELTON ${ }^{2}$ \\ C. ROUZIOUX ${ }^{3}$ \\ P. BERCHE ${ }^{3}$}

H. KREIS ${ }^{1}$

Unité de Transplantation, Départment de Néphrologie, ${ }^{1}$ Laboratoire d'Immuno-Hématologie, Centre de Transfusion Sanguine, ${ }^{2}$ and Laboratoire de Virologie, ${ }^{3}$ Hopital Necker, Paris, France

Summary Cytomegalovirus (CMV) infections in renal transplant recipients must be diagnosed rapidly, since they can be life-threatening unless chemotherapy is started early. Detection of granulocyteassociated immunoglobulins was compared with conventional virological methods for diagnosis of $\mathrm{CMV}$ infection in 71 renal transplant recipients. The granulocyteassociated immunoglobulin test (GAIT) was positive in 31 of 34 patients with proven CMV infections on the day of admission. By conventional virological criteria the diagnosis of active CMV infection could be made only 3-24 days later. The GAIT remained negative in 14 healthy transplant recipients, but it was positive in 9 of 23 patients with non-CMV-related post-transplantation complications. The GAIT, which is not a virological method, could be useful for rapid diagnosis of $\mathrm{CMV}$ infection; its sensitivity was 0.91 and specificity 0.82 (for patients without detectable immunoglobulins on erythrocytes or platelets) and the processing time is only $3 \mathrm{~h}$.

\section{INTRODUCTION}

THE use of various immunosuppressive agents to reduce the $\mathrm{T}$-cell response to alloantigens has led to an increasing number of viral infections, many due to cytomegalovirus $(\mathrm{CMV}) \cdot{ }^{1-3}$ Clinical features such as fever, leucopenia, ${ }^{4}$ renal failure, high serum levels of liver enzymes, and pneumopathy strongly suggest active CMV infection. On the other hand, in a febrile transplant recipient, declining function of the transplanted organ, possibly reflecting a rejection episode, can be difficult to differentiate from active CMV infection. Similarly, leucopenia during a febrile episode can be due either to CMV infection or to drug toxicity. The diagnosis of CMV infection can be confirmed only by blood, bronchial aspirate, or spinal fluid culture and/or the appearance of anti-CMV $\operatorname{IgM}$ antibodies in a previously seronegative patient. Unfortunately, both cultures and serological tests can take a long time to become positive, thus delaying initiation of anti-CMV chemotherapy and rendering it less effective. Rapid diagnostic methods have been developed, but even with these methods, which require a previous short culture period, the processing time is $1-4$ days. ${ }^{5.6}$ Two others, without a previous short culture, take $4-8 \mathrm{~h}$ but are still under evaluation and not yet widely available. ${ }^{7}$ 